\title{
Variability of Sugarcane Wilt Pathogen in North Coastal Zone of Andhra Pradesh
}

\author{
V. Chandra Sekhar*, P. Kishore Varma, B. Swapna, \\ M. Suresh and M. Bharathalakhsmi
}

Regional Agricultural Research Station, Anakapalle-531 001, India

*Corresponding author

\section{A B S T R A C T}

Keywords

Variability,

Fusarium sacchari, Sugarcane, Wilt

Article Info

Accepted:

22 January 2021

Available Online:

10 February 2021
An investigation has been carried to assess the variability in wilt pathogen of sugarcane, Fusarium saccahri, with reference to its cultural, morphological, molecular and pathogenic characters in North Coastal Zone of Andhra Pradesh. Twelve samples of wilt infected sugarcane were collected from the north coastal zone of Andhra Pradesh and evaluated for their variability. Albeit very limited variability was observed with respect to cultural, morphological and molecular characters but considerable variation was found with respect to pathogenicity. Ten host differentials having different degrees of wilt reaction were selected to evaluate the pathogenicity of 12 isolates of $F$. sacchari. Among the sugarcane differentials studied, 2012A 246 had shown highest degree of susceptibility for two consecutive years, viz., 2018-19 and 20192020. Similarly the isolate collected from Bheemasingi, FS-12, had exhibited maximal pathogenicity during the cropping season 2018-2019. The study suggests that although the isolates haven't shown much variation in cultural and morphological characters they exhibited considerable degree of pathogenic variability.

\section{Introduction}

India has been known as the original home of sugarcane and sugar. India is the second largest producer of sugar in the World after Brazil and produces more of cane sugar. Sugarcane is an economically important crop which is propagated through vegetative means in the tropics and sub-tropics. In our country this is a major cash crop used as the chief source for sugar and ethanol production (as a renewable source of bio-fuel). This crop is incited by all sought of microorganisms starting from fungi to viruses leading to many diseases. Among the fungal diseases of sugarcane, wilt is one of the major disease which led to elimination of several commercial varieties affecting sugarcane production and productivity in the country. In fact many succumbed varieties vanished from 
the sphere of cultivation. Wilt epidemics during early decades of the last century resulted in elimination of several commercial varieties like Co 245, Co 321, Co 527, Co 951, Co 1107 and Co 1223 (Kirtikar et al., 1972). In parts of Tamil Nadu in tropical India, the disease caused serious damage during 1955-56 to the varieties, Co 419, Co 449, Co 453, and Co 527 and Co 1122. Sarma (1976) reported that loss in the yield might go as high as $65 \%$ and the incidence of the disease is more in ratoon as compared to the plant crop. Occurrence of this disease can cause yield losses as high as $90 \%$ in association with stalk borer in highly susceptible varieties (Waraitch, 1981). In many instances, complete loss to cane production had occurred, as in $\mathrm{CoC} 671$ in Gujarat state, in Co 89003 in Punjab and in other varieties in Bihar state (Agnihotri and Rao, 2002). Several commercial varieties were withdrawn from cultivation in North and southern parts of India due to wilt (Agnihotri and Rao, 2002; Viswanathan and Rao, 2011). Besides reduction in cane yield, the wilt causes 14.6 to $25.8 \%$ reduction in juice extraction and 3 to $20 \%$ in sugar recovery (Gupta and Gupta, 1976).

The deterioration in juice quality is due to the decrease in sucrose content (Khanna and Chacravarti, 1949) and an increase in reducing sugars, gums, titrable acidity, flavonoids and soluble salts (Singh and Waraitch, 1981), which adversely affect processing of white sugar in the mills. This wilt disease is caused by Fusarium sacchari is considered to be one of the earliest recorded sugarcane diseases in India.

Butler and Khan (1913) described a stem rot disease in India and designated as 'wilt' and noted Cephalosporium sacchari as the causal agent. However, Bourne (1922) recorded a stem rot disease of the basal portions of unwounded sugarcane stems having a species of Fusarium associated with the disease in
Barbados. During the same period, Fawcett (1922) also recorded a Fusarium sp. associated with a dry rot and ratoon rot of this crop in Argentina.

The disease had prevailed to varying intensities for the past 100 years in India. Although there were reports on the disease incidences in different periods, only recently Viswanathan et al., (2006) made detailed surveys in all the sugarcane growing areas and they reported that the disease severity is highest in Gujarat state, east coastal regions in Tamil Nadu, Andhra Pradesh and Orissa in tropical India. The most affected varieties were Co 7805 and Co 86032 in Andhra Pradesh. Despite the disease was reported long back, the information on pathogen(s) involved and their variability was confined to limited extent.

In the past many promising varieties from north coastal region of Andhra Pradesh with commercial value having considerable resistance to this pathogen were lost because of this wilt pathogen (Viswanathan et al., 2006) which may be attributed to the development of variability in the pathogen. Therefore there is a profound need to characterize the pathogen with respect to its variability from all major sugarcane areas of North Coastal region of Andhra Pradesh. In view of its necessity the present research focused to assess the variability of this pathogen by considering the characters like cultural variation, morphology, molecular identity and pathogenic variability.

\section{Materials and Methods}

The details of the collection are mentioned in the table 1. From the collected samples the pathogen was isolated using standard procedure and maintained for future studies. A small bit of infected tissue was cut under aseptic conditions and surface sterilized with $0.1 \%$ mercuric chloride solution for 30- 60 
seconds and immediately washed with sterile distilled water thrice and transferred to the Petri plates consisting of potato dextrose agar medium. After 5 to 7 days the Petri plates were screened for Fusarium sacchari presence. All the collected isolates were designated as FS- series. For maintaining the cultures, Potato Dextrose Agar medium in Petri plates and test tubes were used. Similarly for long term preservation the cultures were maintained in glycerol solution.

\section{Morphological and cultural characterization}

The collected isolates were studied for cultural and morphological characters. To study the cultural variation, the growth rate and reverse pigmentation of the mycelial growth were considered.

For the calculation of average growth rate, the fungal mycelium disc was inoculated at the centre of the Petri plate and the average growth rate of each isolate was calculated by considering five replicated plates on $7^{\text {th }}$ day after inoculation.

Whereas, to study the morphological variation, the size, shape and color of the macro and micro conidia were considered. The average size of the conidia was measured using Nikon Eclipse E200 Compound microscope equipped with Vimage softare. Minimum of 10 conidia were considered for length and width for the average size. For all isolates micrographs were captured at $40 \mathrm{x}$ magnification.

\section{Molecular Characterization}

To confirm the molecular identity of the collected isolates DNA was isolated from pure culture (mycelial mat) of the fungal isolates. Seven day old culture maintained on Potato dextrose broth was used for the DNA isolation. The isolation of the DNA was done using modified CTAB (Cetyl trimethyl Ammonium Bromide) method of White et al., 1990. Fungal mycelium of $0.2 \mathrm{~g}$ were grounded using liquid nitrogen in sterilized pestle and mortar, then transferred to $1.5 \mathrm{ml}$ eppendorf micro tubes. $600 \mu \mathrm{l}$ of preheated $\left(60{ }^{0} \mathrm{C}\right) 2 \mathrm{X}$ CTAB extraction buffer $(2 \%$ (w/v) CTAB, $100 \mathrm{mM}$ Tris $\mathrm{HCl}, 1.4 \mathrm{M} \mathrm{NaCl}$, 20mM EDTA, $\mathrm{pH}$ 8.0) was added to the eppendorf micro tubes. The solution was incubated for one hour at $60^{\circ} \mathrm{C}$ in water bath with intermittent gentle stirring. An equal volume of phenol: chloroform: isoamyl alcohol $(25: 24: 1)$ was added to this solution and mixed thoroughly. Subsequently, the mixture was centrifuged at $10,000 \mathrm{rpm}$ for 20 $\min$ at $24{ }^{\circ} \mathrm{C}$.

Aqueous phase was separated and transferred to a fresh tube. An equal volume of phenol: chloroform: isoamyl alcohol (25:24:1) was added to this aqueous phase and mixed thoroughly, then centrifuged at $10,000 \mathrm{rpm}$ for $20 \mathrm{~min}$ at $24^{0} \mathrm{C}$. These steps were repeated 23-times till a clear aqueous phase was obtained. To this clear aqueous phase, 0.6 volume of ice cold isopropanol and 0.1 volume of sodium acetate buffer $(3 \mathrm{M})$ were added and incubated at $-20{ }^{0} \mathrm{C}$ for 30 minutes. DNA was precipitated by centrifuging at $10,000 \mathrm{rpm}$ for $10 \mathrm{~min}$ at $4{ }^{0} \mathrm{C}$. The precipitate was treated with $75 \%$ ethanol and centrifuged at $10,000 \mathrm{rpm}$ for $10 \mathrm{~min}$ at $4{ }^{0} \mathrm{C}$, then the precipitate was discarded.

The DNA was dried under a regular air flow for $20 \mathrm{~min}$, re-suspended in 70 $\mu \mathrm{l}$ TE buffer and stored at $-20{ }^{\circ} \mathrm{C}$. The presence of DNA in the samples was further confirmed by separating them on $1.2 \%$ agarose gel at 80 volts for 45 minutes using gel electrophoresis unit. The concentration of DNA was measured spectrophotometrically using Denovix DS11spectrophotometer. The isolated fungal DNA was used for future analysis. 


\section{PCR amplification}

The molecular identification of the isolates was done using ITS primers ITS1 (5'TCCGTAGGTGAACCTGCGG-3') and ITS2 (5'-GCTGCGTTCTTCATCGATGC-3').

Polymerase Chain Reaction (PCR) was carried out in flat capped $200 \mu \mathrm{L}$ volume PCR tubes obtained from M/s Tarsons, Kolkata, India. PCR amplification of the partial region of ITS was performed in a $20 \mu \mathrm{l}$ reaction mix containing $5 \mathrm{X}$ reaction buffer, $25 \mathrm{mM} \mathrm{MgCl}$, $0.01 \mathrm{mM}$ dNTPs, $0.001 \mathrm{M}$ primers, $1 \mathrm{U}$ of TaqDNA polymerase (Genei) and $100 \mathrm{ng}$ DNA total. PCR amplifications were performed on a DNA thermocycler (Eppendorf) with the following program: an initial denaturation at $97{ }^{0} \mathrm{C}$ for $6 \mathrm{~min}$ followed by 35 amplification for cycles of 94 ${ }^{0} \mathrm{C}$ for $1 \mathrm{~min}, 58{ }^{\circ} \mathrm{C}$ for $1 \mathrm{~min}, 72{ }^{0} \mathrm{C}$ for $2 \mathrm{~min}$ followed by final extension at $72{ }^{\circ} \mathrm{C}$ for $7 \mathrm{~min}$.

\section{DNA sequencing}

The amplified samples were chromatographed by gel electrophoresis on $1.2 \%$ agarose. The gel was photographed using gel documentation system. Amplicons of 500 to $600 \mathrm{bp}$ were selected for sequencing the ITS region. For size selection a co-resolved $10 \mathrm{~kb}$ ladder was used. The amplified products were outsourced to Bioserve Biotechnologies (India) Pvt., Ltd., Hyderabad for sequencing.

\section{Molecular identification}

Molecular identification of fungus was done using partial amplified nucleotide sequences of ITS region through NCBI, BLAST programme and checked for homology. The ITS generated sequence was deposited in NCBI Gene Bank database to obtain the accession numbers.

\section{Phylogeny tree construction}

Using maximum parsimony method in MEGA software (Ver. 10.0.5), a phylogenetic tree was constructed by considering most relevant sequences from the NCBI database along with sequence data of F.sacchari isolated in this investigation. The phylogeny was depicted in the following Figure 4.

\section{Pathogenic variability}

To assess the pathogenic variability, the fungal isolates were multiplied on potato dextrose agar medium till 7 days. From seven day old cultures, spore suspension was prepared for all the twelve $F$. sacchari isolates and utilized for inoculation onto ten sugarcane genotypes by plug method. Those ten genotypes include 87A 298, 2012A 145, 2012A 149, 2012A 246, 2012A 249, 2012A 340, 2012A 23, 2012A 264, 2012A 279 and Co13031. All these genotypes were selected based on previous wilt reaction. The field trials were conducted for two cropping seasons, viz., 2018-2019 and 2019-2020, and the same genotypes were maintained during these two years to assess the pathogenic variability. 7 months old crop is being utilized for the purpose of inoculation into the sugarcane plant. In each sugarcane differential, all the 12 isolates of the wilt pathogen were inoculated. $2 \mathrm{ml}$ of spore suspension was injected at second internodal region from the base of the plant. Likewise for each fungal isolate, 20 canes were inoculated in each genotype. The wilt occurrence was recorded on $90^{\text {th }}$ day from the date of inoculation. The following parameters were considered for recording severity of wilt disease. After 90 days of inoculation, 10 clumps were uprooted, split open longitudinally and the wilt severity index scored on a 0- 4 scale. The scale was adopted to record wilt severity as per the details provided in the table 2 and 3.

The wilt severity was calculated using the following formula. 
Mean wilt severity index $=\frac{\text { Sum of wilt incidences of individual stalks }}{-\frac{\text { Number of stalk samples }}{}}$

\section{Results and Discussion}

\section{Cultural and Morphological Variability}

The cultural characters such as average growth rate, mycelial colour, and reverse pigmentation were considered to assess the variability for all the twelve isolates. The results were depicted in the table 4 . Average growth rate of this fungus ranged from 6.2 to $7.3 \mathrm{~cm}$ on seventh day.

Among the strains studied, least growth was exhibited by FS-5 and the highest was observed in FS-8. Certain strains like FS-1, FS-2, FS-4, FS-7 and FS-12 have exhibited significant variation in growth rate when compared to FS-8 strain.

Similarly other strains viz., FS-6 and FS-11 are significantly different from the strains FS1, FS-7 and FS-12. Viswanathan et al., (2013) have clustered $F$. sacchari isolates into 7 groups based on variability observed against growth rate of this pathogen.

In our study also though many strains have not shown much variation with respect to growth rate but certain strains exhibited some degree of variation.

All the strains were also studied for colony colour and reverse pigmentation. From the Fig. 1, the colony colour of the isolates appeared as different degrees of pink but along with the pinkish coloration the isolates, viz., FS-1, FS-3, FS-6, FS-10, FS-11 also have delineated with profuse white mycelium. Similarly the reverse pigmentation also varied among the isolates from reddish to brown colour. These observations were in concordance with Poongothai et al., (2014) who observed enormous variation with cultural characters.

The isolates were also studied for morphological characters. The characters like size, shape, colour and septation were studied for both micro and macroconidia. The conidial dimensions were depicted in the table 4 .

From the Fig. 2 it is evident that in most isolates the shape of the micoconidia appeared to be oval except in FS-3, FS-6, FS-9, FS-10 and FS-11 where it was oval to ellipsoidal. The size of the microconidia ranged between 10.1 to $10.9 \mu \mathrm{m}$ and micro conidia of all the isolates were colourless and aseptate. In 2013 Viswanahtan et al., have performed an extensive morphological study of this pathogen.

They have isolated about 263 Fusarium isolates from 346 wilt infected cane / soil samples collected from 15 states in the country and studied the morphological aspects of types of conidia produced, their shape, types of phialides production, conidial formation and germination and chlamydospore production in selected 117 isolates to characterize the pathogenic isolates for their morphological characters. In their study they found that all the isolates from the states of Andhra Pradesh produced obovoid microconidia.

In contrary to that in our study some isolates have microconidia with oval shape to ellipsoidal. In our study macroconidial size ranged between 43.5 to $44.9 \mu \mathrm{m}$ with hyaline and 3-5 septa having slightly curved apical cell. The present findings were matched with the investigation performed by Viswanathan $e t$ al., in 2013 wherein they found macroconidia with straight to falcate and the apical and basal cells with either conical or blunt end.

The population size and spatial distribution may be attributing for higher variation for his 
studies. Nevertheless Nelson (1994) opined that cultural and morphological characters alone are insufficient to characterize the isolates.

\section{Molecular identification}

The molecular studies will help to futuristic studies to find pathogenesis, detection and evolution of this pathogen on sugarcane crop. With that intention PCR amplification of the collected species of fungal isolates was done using the primers ITS1 and ITS4.

ITS is DNA bar coding region having rDNA sequence that has been widely used to identify and perform phylogenetic analysis of the fungal species (Balazy et al., 2008). In the present study the sequence length of the ITS region was found to be 500-550 bp. Gel photo of 12 amplified products is shown in the Fig. 3 .

By means of the NCBI BLAST algorithm, we found that ITS sequences of the collected fungal isolates were highly homologous to those sequences of Fusarium sacchari.

The identification percentage was found to be 91-100\%. This confirms that ITS sequences were belonging to Fusarium sacchari. Thus the isolates were identified molecularly as Fusarium sacchari. The molecular identification along with NCBI accession numbers were depicted in the table 5 .

Molecular techniques can be used to confirm cultural and morphological characterization of different fungal species (Lenc et al., 2008). Nucleotide sequence variation in the DNA sequences was used to distinguish between species (O’Donnell et al., 1998).

Duggal et al., (1997) have stated that among different regions of fungal identification, ITS region had shown highest polymorphism within Fusarium spp.

Therefore identification of Fusarium spp. using PCR amplification of ITS region of the rDNA using the right primer pairs is quick, accurate and reliable.

In the present investigation the two primers viz., ITS 1 and ITS 4, were used for the identification of Fusarium species. PCR amplification of Fusarium with ITS primers 1 $\& 4$ yielded an estimated 550 - 600-bp product.

Using twelve isolates from Fusarium, we amplified about 500-550 bp DNA fragment of the ITS region and all the twelve sequences of the isolates were deposited in the GenBank and assigned with accession numbers MT981199, MW027267, MT981201, MT981202, MW027268, MT981204, MT981205, MT981206, MT981207, MW027269, MW027270 and MW027271. BLASTn

(http://www.ncbi.nlm.nih.gov/BLAST) analysis of the ITS locus of FS-1, FS-2, FS-3, FS-10 and FS-11 displayed 100\% homology to ITS locus of $F$. sacchari in the GenBank, whereas the ITS region of the other isolates viz., FS-4, FS-5, FS-6, FS-7, FS-8, FS-9, FS12 have displayed $91.95 \%, 93.88 \%, 99.10 \%$, $99.47 \%, 95.93 \%, 99.43$ and $94.03 \%$ homology with other isolates of $F$. sacchari. Thus all collected isolates in the study were identified as Fusarium sacchari molecularly.

The Phylogenetic tree (dendrogram) based on the ITS sequences was constructed using maximum parsimony method employing 1000 boot strap replications and the results were depicted in the Fig. 4. 
Table.1 Details of the isolates collected from the NC Zone of Andhra Pradesh

\begin{tabular}{|c|c|c|}
\hline \multicolumn{2}{|c|}{ Fusarium sacchari isolates collected during 2017-18. } \\
\hline $\begin{array}{c}\text { S1. } \\
\text { No. }\end{array}$ & Place of Collection & $\begin{array}{c}\text { Designated name of the } \\
\text { Isolate }\end{array}$ \\
\hline 1 & Munagapaka, Visakhapatnam & FS-1 \\
\hline 2 & Lakkavaram, Visakhapatnam & FS-2 \\
\hline 3 & Choochukonda, Visakhapatnam & FS-3 \\
\hline 4 & Veduruparhti, Visakhapatnam & FS-4 \\
\hline 5 & Juthada, Visakhapatnam & FS-5 \\
\hline 6 & Achuthapuram, Visakhapatnam & FS-6 \\
\hline 7 & Mukundapuram, Sankili, Srikakulam & FS-7 \\
\hline 8 & Palakonda, Srikakualam & FS-8 \\
\hline 9 & Therlam, Vizianagaram & FS-9 \\
\hline & Fusarium sacchari isolates collected during 2018-19 \\
\hline 1 & Govada (cv. Co62175), Visakhapatnam & FS-10 \\
\hline 2 & Mallepaka (cv. 81V 48), Visakhapatnam & FS-11 \\
\hline 3 & Bheemasingi, Vizianagaram & FS-12 \\
\hline
\end{tabular}

\begin{tabular}{|c|c|}
\hline \multicolumn{2}{|c|}{ Table.2 Scale for grading of wilt disease in sugarcane } \\
\hline Scale & Grading \\
\hline $\mathbf{0 . 0 - 0 . 9}$ & Resistant \\
\hline $\mathbf{1 . 0 - 1 . 9}$ & Moderately Resistant \\
\hline $\mathbf{2 . 0 - 2 . 9}$ & Moderately susceptible \\
\hline $\mathbf{3 . 0 - 3 . 9}$ & Susceptible \\
\hline $\mathbf{> 4 . 0}$ & Highly Susceptible \\
\hline
\end{tabular}

\begin{tabular}{|c|c|}
\hline Grade & Table.3 Description of various grades of wilt severity scale \\
\hline $\mathbf{0}$ & Symptom \\
\hline $\mathbf{1}$ & $\begin{array}{c}\text { Healthy canes and roots with no external symptoms of wilt } \\
\text { formation with yellow discolouration of the internal tissues in one or two lower } \\
\text { internodes only. No cavity formation or fungal growth seen. Apparently normal and } \\
\text { healthy roots }\end{array}$ \\
\hline $\mathbf{2}$ & $\begin{array}{c}\text { Mild yellowing of top leaves and drying of lower leaves, mild stunting and shrinking of } \\
\text { the stalk and rind. Yellowish discolouration of internal tissues extending to three or four } \\
\text { bottom internodes. Slight cavity formation of the pith, no fungal growth seen, slightly } \\
\text { discoloured roots. }\end{array}$ \\
\hline $\mathbf{3}$ & $\begin{array}{c}\text { Mild yellowing of top leaves and drying of lower leaves, mild stunting and shrinking of } \\
\text { the stalk and rind. Light brown discolourations of the internal tissue throughout the } \\
\text { entire length of the cane expect the top. Severe pith and cavity formation. Sparse fungal } \\
\text { growth observed in the pith cavities. }\end{array}$ \\
\hline $\mathbf{4}$ & $\begin{array}{c}\text { Complete yellowing and death of the leaves, marked stunting, shrinking and drying of } \\
\text { the stalk and rind, dark brown discolouration of the internal tissues extending } \\
\text { throughout the entire length of the cane. Large pith cavities with profuse over growth of } \\
\text { the associated fungi. Most of the roots necrotic with dark discolouration which dislodge } \\
\text { easily from the stalks. Roots mildly discoloured and slightly necrotic. }\end{array}$ \\
\hline
\end{tabular}




\begin{tabular}{|c|c|c|c|c|c|c|c|c|c|c|}
\hline \multicolumn{11}{|c|}{ Table.4 Cultural and Morphological variability of Fusarium sacchari isolates } \\
\hline \multirow[t]{2}{*}{ Strain } & \multirow{2}{*}{$\begin{array}{c}\text { Average } \\
\text { Growth } \\
\text { Rate } \\
\text { (cm) }\end{array}$} & \multirow{2}{*}{$\begin{array}{c}\text { Reverse } \\
\text { Pigmentation }\end{array}$} & \multicolumn{4}{|c|}{ Microconidia } & \multicolumn{4}{|c|}{ Macroconidia } \\
\hline & & & Shape & $\begin{array}{l}\text { Size } \\
(\mu \mathrm{m})\end{array}$ & $\begin{array}{c}\text { Co } \\
\text { lou } \\
\mathbf{r}\end{array}$ & Septation & $\begin{array}{l}\text { S } \\
\text { h } \\
\mathbf{a} \\
\mathbf{p} \\
\mathbf{e}\end{array}$ & $\begin{array}{l}\text { Size } \\
(\mu \mathrm{m})\end{array}$ & $\begin{array}{l}\text { Col } \\
\text { our }\end{array}$ & Septation \\
\hline FS-1 & 6.3 & $\mathbf{R}$ to $\mathbf{B}$ & $\mathbf{O}$ & $\begin{array}{c}10.5 \\
(5.7-18.8)\end{array}$ & $\mathbf{H}$ & A & $\mathbf{C}$ & $\begin{array}{c}44.6 \\
(31.5 \text { to } 65.3)\end{array}$ & $\mathbf{H}$ & 3 to $5 \mathrm{~S}$ \\
\hline FS-2 & 6.5 & $\mathbf{R}$ to $\mathbf{B}$ & $\mathbf{O}$ & $\begin{array}{c}10.3 \\
(6.2-18.1)\end{array}$ & $\mathbf{H}$ & $\mathbf{A}$ & $\mathbf{C}$ & $\begin{array}{c}43.5 \\
(29.8 \text { to } 70.5)\end{array}$ & $\mathbf{H}$ & 3 to $5 \mathrm{~S}$ \\
\hline FS-3 & 7.0 & $R$ to $B$ & $\begin{array}{c}\text { O to } \\
\mathbf{E}\end{array}$ & $\begin{array}{c}10.7 \\
(6.0 \text { to } \\
18.4)\end{array}$ & $\mathbf{H}$ & $\mathbf{A}$ & C & $\begin{array}{c}44.9 \\
(32.5 \text { to } 69.1)\end{array}$ & $\mathbf{H}$ & 3 to $5 \mathrm{~S}$ \\
\hline FS-4 & 6.6 & $R$ to $B$ & $\mathbf{O}$ & $\begin{array}{c}10.4 \\
(5.6 \text { to } \\
18.9)\end{array}$ & $\mathbf{H}$ & $\mathbf{A}$ & $\mathbf{C}$ & $\begin{array}{c}43.9 \\
(33.5 \text { to } 63.5)\end{array}$ & $\mathbf{H}$ & 3 to $5 \mathrm{~S}$ \\
\hline FS-5 & 6.2 & $R$ to $B$ & O & $\begin{array}{l}10.5 \\
(6.5 \text { to } \\
18.6) \\
\end{array}$ & $\mathbf{H}$ & $\mathbf{A}$ & C & $\begin{array}{c}44.2 \\
(29.8 \text { to } 67.8)\end{array}$ & H & 3 to $5 \mathrm{~S}$ \\
\hline FS-6 & 7.1 & $R$ to $B$ & $\begin{array}{c}\text { O to } \\
\text { E }\end{array}$ & $\begin{array}{c}10.6 \\
(5.9 \text { to } \\
16.3)\end{array}$ & H & $\mathbf{A}$ & C & $\begin{array}{c}43.5 \\
(26.4 \text { to } 65.4)\end{array}$ & $\mathbf{H}$ & 3 to $5 S$ \\
\hline FS-7 & 6.3 & $R$ to $B$ & O & $\begin{array}{c}10.7 \\
(7.2 \text { to } \\
17.7) \\
\end{array}$ & H & $\mathbf{A}$ & C & $\begin{array}{c}43.9 \\
(32.3 \text { to } 69.9)\end{array}$ & $\mathbf{H}$ & 3 to $5 \mathrm{~S}$ \\
\hline FS-8 & 7.3 & $R$ to $B$ & $\mathbf{O}$ & $\begin{array}{l}10.5 \\
(6.6 \text { to } \\
18.5)\end{array}$ & $\mathbf{H}$ & $\mathbf{A}$ & $\mathbf{C}$ & $\begin{array}{c}44.1 \\
(35.6 \text { to } 68.5)\end{array}$ & $\mathbf{H}$ & 3 to $5 S$ \\
\hline FS-9 & 6.9 & $R$ to $B$ & $\begin{array}{c}\text { O to } \\
\mathbf{E}\end{array}$ & $\begin{array}{c}10.5 \\
(7.3 \text { to } \\
17.6) \\
\end{array}$ & $\mathbf{H}$ & $\mathbf{A}$ & C & $\begin{array}{c}44.5 \\
(30.9 \text { to } 69.5)\end{array}$ & $\mathbf{H}$ & 3 to $5 \mathrm{~S}$ \\
\hline FS-10 & 6.8 & $R$ to $B$ & $\begin{array}{c}\text { O to } \\
\mathbf{E}\end{array}$ & $\begin{array}{c}10.9 \\
(7.3 \text { to } \\
15.6)\end{array}$ & $\mathbf{H}$ & $\mathbf{A}$ & $\mathbf{C}$ & $\begin{array}{c}43.6 \\
(28.9 \text { to } 69.5)\end{array}$ & H & 3 to $5 \mathrm{~S}$ \\
\hline FS-11 & 7.0 & $R$ to $B$ & $\begin{array}{c}\text { O to } \\
\text { E }\end{array}$ & $\begin{array}{c}10.3 \\
(6.7 \text { to } \\
16.6) \\
\end{array}$ & $\mathbf{H}$ & A & $\mathbf{C}$ & $\begin{array}{c}44.8 \\
(30.9 \text { to } 69.5)\end{array}$ & $\mathbf{H}$ & 3 to $5 \mathrm{~S}$ \\
\hline FS-12 & 6.3 & $R$ to $B$ & $\mathbf{O}$ & $\begin{array}{c}10.1 \\
(8.5 \\
\text { to18.4) }\end{array}$ & $\mathbf{H}$ & $\mathbf{A}$ & $\mathbf{C}$ & $\begin{array}{c}44.3 \\
(30.9 \text { to } 69.5)\end{array}$ & $\mathbf{H}$ & 3 to $5 \mathrm{~S}$ \\
\hline CD & 0.622 & & & & & & & & & \\
\hline $\mathrm{CV}$ & 2.449 & & & & & & & & & \\
\hline
\end{tabular}




\begin{tabular}{|c|c|c|c|}
\hline \multicolumn{4}{|c|}{ Table.5 Molecular identification of collected fungal isolates } \\
\hline SI No & Isolate & ITS identification & NCBI Accession number \\
\hline 1 & FS-1 & Fusarium sacchari & MT981199 \\
\hline 2 & FS-2 & Fusarium sacchari & MW027267 \\
\hline 3 & FS-3 & Fusarium sacchari & MT981201 \\
\hline 4 & FS-4 & Fusarium sacchari & MT981202 \\
\hline 5 & FS-5 & Fusarium sacchari & MW027268 \\
\hline 6 & FS-6 & Fusarium sacchari & MT981204 \\
\hline 7 & FS-7 & Fusarium sacchari & MT981205 \\
\hline 8 & FS-8 & Fusarium sacchari & MT981206 \\
\hline 9 & FS-9 & Fusarium sacchari & MT981207 \\
\hline 10 & FS-10 & Fusarium sacchari & MW027269 \\
\hline 11 & FS-11 & Fusarium sacchari & MW027270 \\
\hline 12 & FS-12 & Fusarium sacchari & MW027271 \\
\hline
\end{tabular}

Table.6 Reaction of twelve Fusarium sacchari isolates on different genotypes of sugarcane (2018-2019)

\begin{tabular}{|c|c|c|c|c|c|c|c|c|c|c|c|c|}
\hline Variety & \multicolumn{10}{|c|}{ Wilt severity index } \\
\cline { 2 - 18 } & FS-1 & $\begin{array}{c}\text { FS- } \\
2\end{array}$ & $\begin{array}{c}\text { FS- } \\
3\end{array}$ & $\begin{array}{c}\text { FS- } \\
4\end{array}$ & $\begin{array}{c}\text { FS- } \\
5\end{array}$ & $\begin{array}{c}\text { FS- } \\
6\end{array}$ & $\begin{array}{c}\text { FS- } \\
7\end{array}$ & $\begin{array}{c}\text { FS- } \\
8\end{array}$ & $\begin{array}{c}\text { FS- } \\
9\end{array}$ & FS-10 & FS-11 & FS-12 \\
\hline 87A 298 & 0.66 & 0.00 & 1.00 & 0.33 & 0.00 & 0.00 & 0.50 & 0.00 & 0.00 & 0.00 & 0.00 & 0.00 \\
\hline 2012A 145 & 0.00 & 0.00 & 0.00 & 0.00 & 0.00 & 0.80 & 1.60 & 0.20 & 0.00 & 0.60 & 0.20 & 1.85 \\
\hline 2012A 149 & 0.40 & 1.00 & 1.00 & 0.00 & 0.80 & 1.40 & 1.00 & 0.16 & 0.20 & 0.00 & 0.00 & 3.80 \\
\hline 2012A 246 & 0.60 & 1.20 & 3.25 & 2.00 & 2.60 & 3.50 & 3.80 & 1.60 & 3.60 & 3.80 & 3.80 & 3.80 \\
\hline 2012A 249 & 1.00 & 3.00 & 1.00 & 1.20 & 0.83 & 0.40 & 0.40 & 0.80 & 1.20 & 0.60 & 0.00 & 0.40 \\
\hline 2012A 340 & 0.40 & 0.00 & 0.16 & 0.20 & 0.00 & 0.00 & 0.00 & 0.00 & 0.20 & 0.00 & 0.00 & 0.00 \\
\hline 2012A 23 & 0.00 & 0.00 & 0.00 & 0.00 & 0.00 & 0.00 & 0.00 & 0.00 & 0.00 & 0.20 & 0.20 & 0.00 \\
\hline 2012A 264 & 0.40 & 0.33 & 0.00 & 0.20 & 0.16 & 0.33 & 0.20 & 0.00 & 2.60 & 0.20 & 0.00 & 0.00 \\
\hline 2012A 279 & 0.00 & 0.40 & 0.00 & 0.20 & 0.50 & 0.20 & 0.00 & 0.60 & 0.20 & 0.00 & 0.00 & 2.12 \\
\hline Co 13031 & 0.00 & 0.00 & 0.00 & 0.50 & 0.66 & 0.00 & 0.00 & 0.00 & 0.00 & 0.00 & 0.00 & 0.00 \\
\hline & 0.69 & 1.19 & 1.28 & 0.93 & 1.11 & 1.33 & 1.50 & 0.67 & 1.60 & 1.08 & 0.84 & 2.39 \\
\hline
\end{tabular}

\begin{tabular}{|c|c|c|c|c|c|c|c|c|c|c|c|c|}
\hline \multirow[t]{2}{*}{ Variety } & \multicolumn{12}{|c|}{ Wilt severity index } \\
\hline & FS-1 & $\begin{array}{c}\text { FS- } \\
2\end{array}$ & $\begin{array}{c}\text { FS- } \\
3\end{array}$ & $\begin{array}{c}\text { FS- } \\
4\end{array}$ & $\begin{array}{c}\text { FS- } \\
5\end{array}$ & $\begin{array}{c}\text { FS- } \\
6\end{array}$ & $\begin{array}{c}\text { FS- } \\
7\end{array}$ & $\begin{array}{c}\text { FS- } \\
8\end{array}$ & $\begin{array}{c}\text { FS- } \\
9\end{array}$ & FS-10 & FS-11 & FS-12 \\
\hline 87A 298 & 2.40 & 1.80 & 1.80 & 0.80 & 0.20 & 0.80 & 1.20 & 0.40 & 0.00 & 2.40 & 1.80 & 1.20 \\
\hline 2012A 145 & 1.00 & 1.80 & 0.20 & 0.00 & 0.20 & 1.80 & 2.00 & 1.20 & 0.00 & 1.60 & 0.60 & 1.00 \\
\hline 2012A 149 & 0.60 & 0.40 & 1.80 & 2.20 & 1.20 & 3.60 & 1.20 & 2.20 & 3.60 & 1.60 & 1.20 & 0.80 \\
\hline 2012A 246 & 2.80 & 0.80 & 3.60 & 2.60 & 1.00 & 0.40 & 1.20 & 1.20 & 0.00 & 1.40 & 0.80 & 1.20 \\
\hline 2012A 249 & 1.80 & 1.20 & 1.20 & 1.20 & 1.40 & 1.60 & 4.00 & 1.00 & 1.40 & 0.60 & 1.60 & 0.20 \\
\hline 2012A 340 & 1.60 & 0.60 & 2.60 & 0.00 & 1.80 & 1.60 & 2.00 & 1.00 & 2.00 & 1.20 & 0.80 & 2.20 \\
\hline 2012A 23 & 0.60 & 0.40 & 0.40 & 0.20 & 0.00 & 0.00 & 0.40 & 0.00 & 0.00 & 0.20 & 1.00 & 1.00 \\
\hline 2012A 264 & 2.40 & 1.60 & 2.00 & 1.80 & 1.40 & 1.20 & 1.20 & 1.00 & 1.60 & 1.60 & 1.60 & 0.80 \\
\hline 2012A 279 & 0.60 & 0.20 & 0.20 & 0.80 & 0.00 & 0.20 & 0.40 & 0.20 & 0.60 & 0.40 & 0.00 & 0.00 \\
\hline \multirow[t]{2}{*}{ Co 13031} & 0.20 & 0.00 & 0.00 & 0.40 & 0.20 & 0.40 & 0.00 & 0.20 & 0.20 & 0.00 & 1.20 & 1.60 \\
\hline & 1.40 & 0.88 & 1.38 & 1.00 & 0.74 & 1.16 & 1.36 & 0.84 & 0.94 & 1.10 & 1.06 & 1.00 \\
\hline
\end{tabular}


Fig.1 Cultural variation of Fusarium sacchari isolates

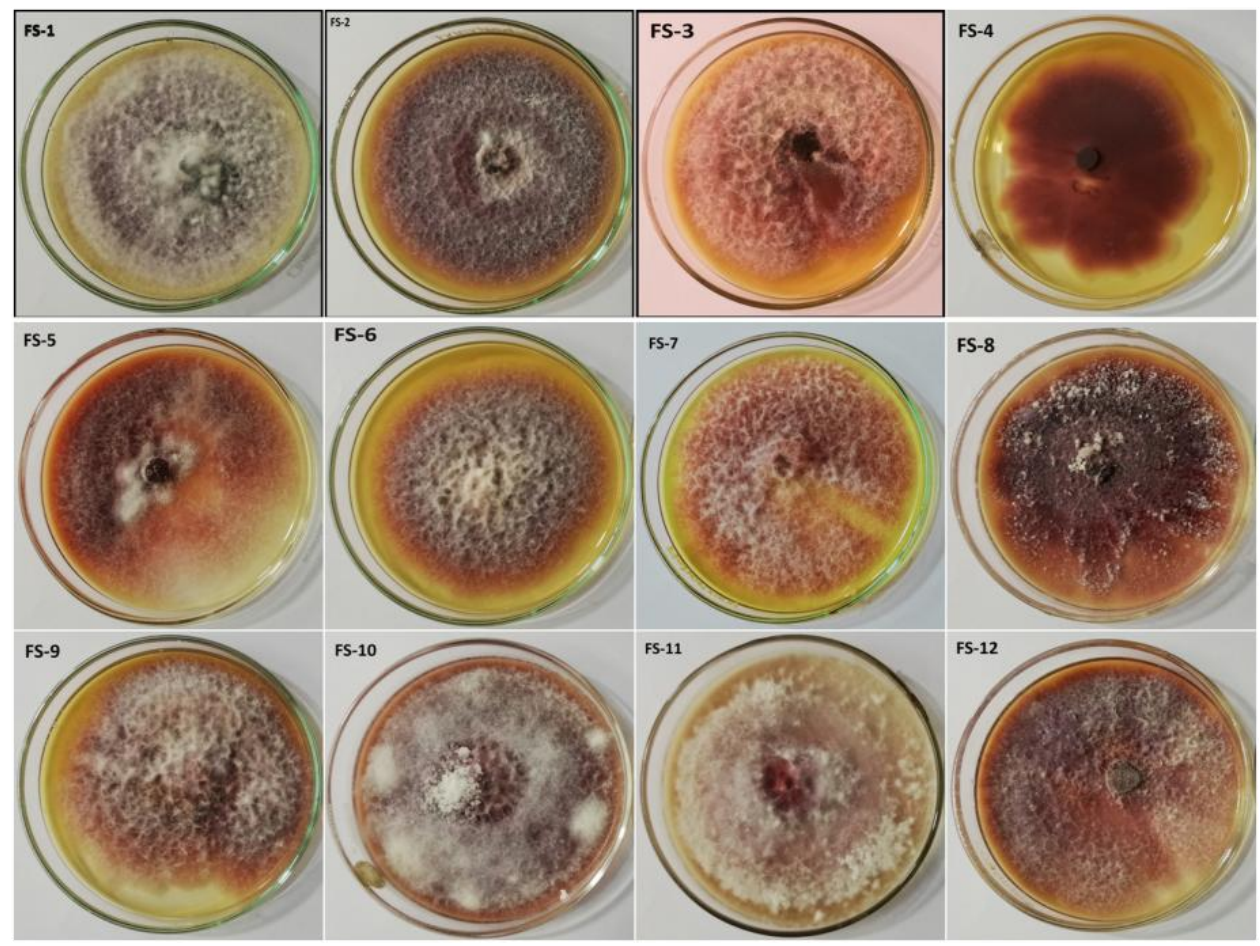

Fig.2 Conidial variation in the Fusarium sacchari isolates

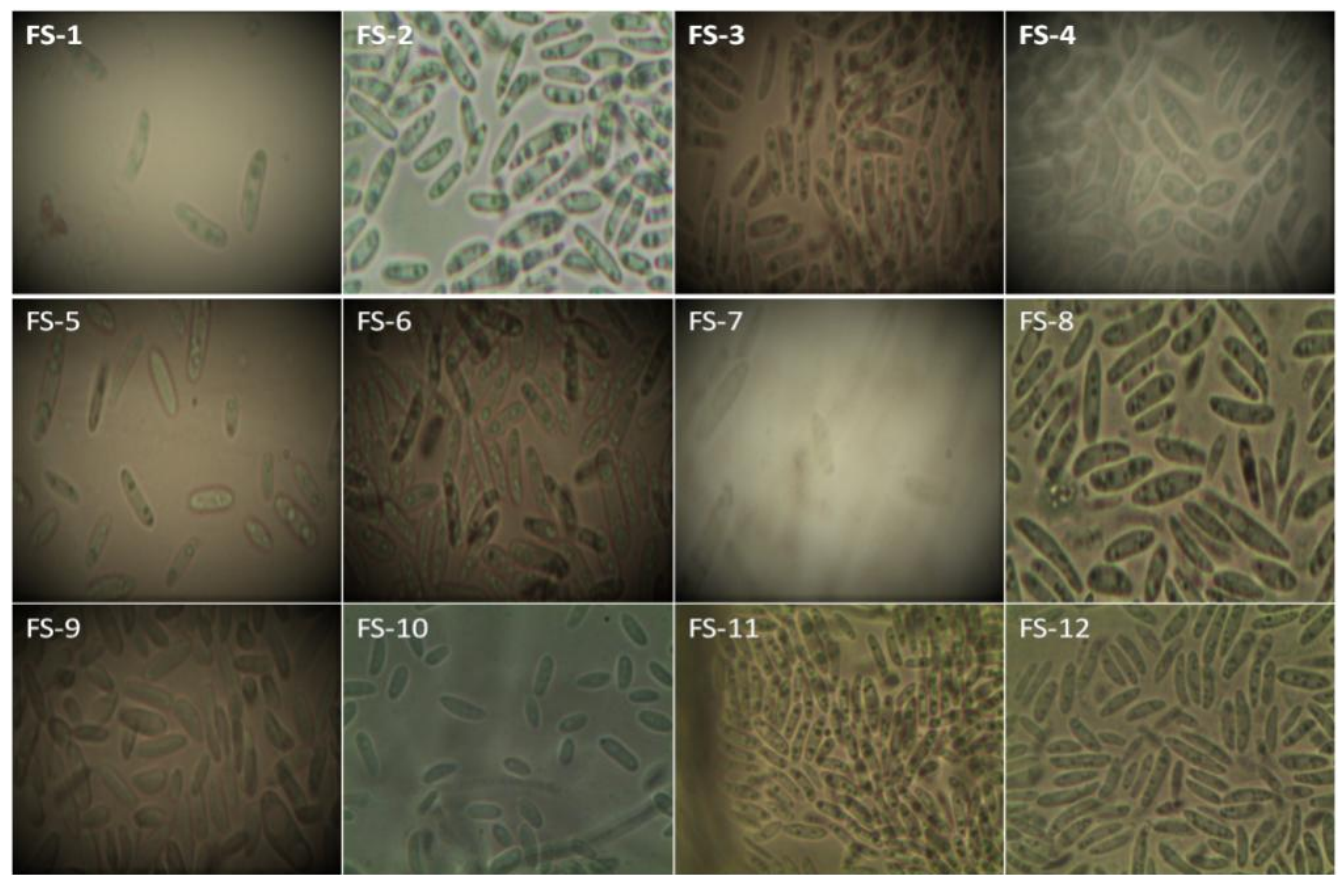


Fig.3

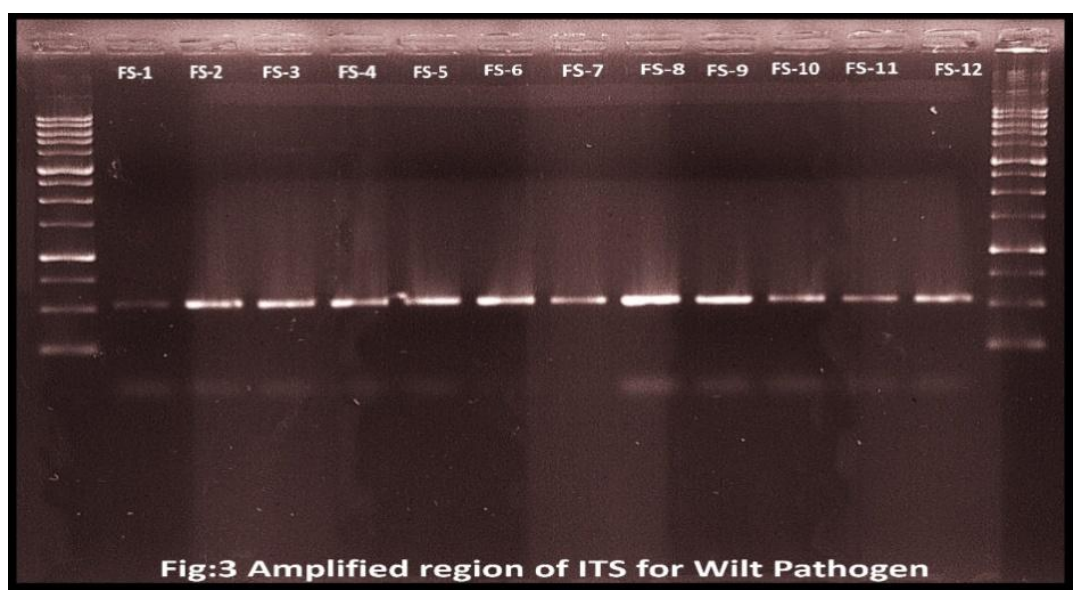

Fig.4 Phylogenetic tree of Fusarium sacchari isolates

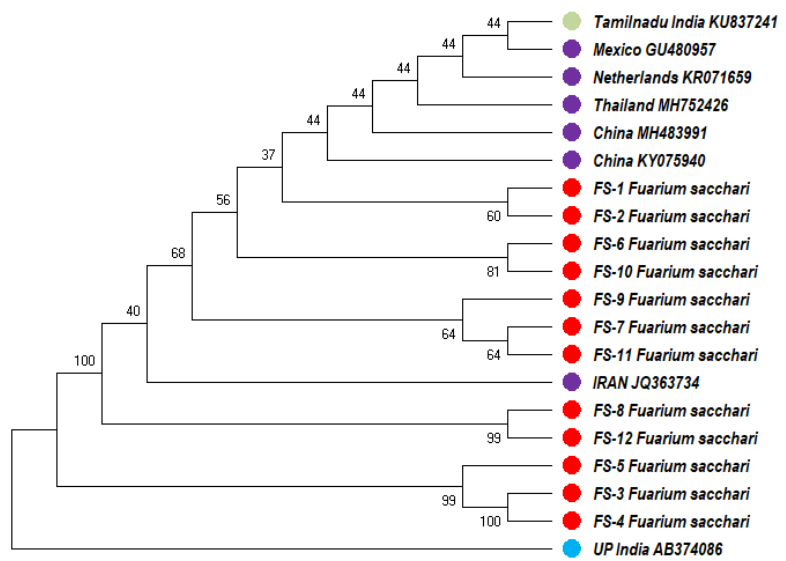

From the dendrogram based on ITS region similarities it is evident that all the twelve isolates of the wilt pathogen were grouped together along with Iranian isolate. This implies all the wilt pathogens have common evolution. Though the Iranian isolate was grouped with all the isolates of the $F$. sacchari, it has formed as separate branch with Fusarium sacchari group. The studies are in concordance with that of Poongothai et al., (2014) who observed that geographical origin have influence in the grouping of this organism when phylogenetic tree was constructed. Similarly Viswanathan et al., (2012) observed higher polymorphic pattern in this pathogen due to collection of the isolates across the country and wide variety of sugarcane hosts for different molecular tools including ITS. This suggests that geographic distribution have impact in the variability of this pathogen.

\section{Pathogenic variability}

The main concern of pathogenic wilt studies is its inoculation in to the host tissue. As per the Viswanathan et al., (2015) the disease can be easily produced in endemic soils. In the present investigation we have selected plug method of inoculation to study pathogenic variability among the isolates. Viswanthan et al., (2015) clearly established that the plug 
method of inoculation with spore suspension is ideal in inducing wilt compared to the soil inoculum in endemic soils. Thus in the present investigation, plug method of inoculation was used for the disease production.

Ten sugarcane genotypes namely 87A 298, 2012A 145, 2012A 149, 2012A 246, 2012A 249, 2012A 340, 2012A 23, 2012A 264, 2012A 279 and Co13031 with varied degrees of resistance to Fusarium sacchari (based on previous studies) were planted under field conditions at Regional Agricultural Research Station, Anakapalle for two consecutive years (2018-2019 and 2019-2020) to study pathogenic variability among $F$. sacchari isolates at field level and the results were depicted in the table 6 and 7. For the wilt severity index, 0 to 4 scale was considered as mentioned in the table 3 and 4 and the wilt severity was recorded.

During the year 2018-2019 among different isolates collected from the table 6, FS-12 has recorded high wilt severity index in comparison with other isolates. The sugarcane genotype, 2012A 246, had shown highest susceptibility across all the collected isolates of Fusarium sacchari. Very few isolates were able to breach the resistance of the sugarcane genotypes, 2012A 23, Co 13031, 2012A 340, 2012A 145 and 87A 298. Hence these genotypes could be used as host differentials to study pathogenic variability in Fusarium sacchari. Using the same sugarcane genotypes in the subsequent year, 2019-2020, the pathogenic variability for collected $F$. sacchari isolates was studied at field level and results were shown in the table no 7 . During this year also like previous year the differential 2012A 246 had shown highest susceptibility across all the collected isolates of Fusarium sacchari followed by 2012A 249. During this year also pathogenic variability was exhibited by all the isolates under study. Further it was also observed that very few isolates have breached the resistance of the sugarcane genotypes, such as 2012A 149, 2012A 249, 2012A 264 and 87A 298. Hence these genotypes could be used as host differentials to study pathogenic variability in Fusarium sacchari. Similar studies were conducted by Viswanathan et al., (2009). Pathogenecity of the collected isolates was studied at different locations of the country viz., Coimbatore, Karnal and Surat under field conditions from 2006 to 2009. In all the three locations, pathogen was inoculated by the plug method into 6-8 months old crop. Evaluation of canes for wilt after 3-5 months of inoculation revealed a clear reproduction of the disease in all the three locations. During their investigation they found that pathogen entry was favoured by climatic conditions and other environmental factors for the disease to build up. At Coimbatore location imposing drought and water logging has led to reproduction of the disease. Weakening of the host tissue by abiotic factors induces pathogen entry in some cultivars and in certain cultivars further weakening by pests was found more effective in inducing the disease.

Among the twelve isolates of F.sacchari limited variability was observed with respect to cultural, morphological and molecular characters but considerable variation was found against pathogenicity on ten sugarcane genotypes. Both morphologically and the molecularly the twelve isolates were identified as Fusarium sacchari. Among the sugarcane genotypes studied for pathogenicity, 2012A 246 had shown highest degree of susceptibility to majority of the isolates tested for two consecutive years, viz., 2018-19 and 20192020. The isolate collected from the Bheemasingi, FS-12, had exhibited maximal pathogenicity during the cropping season 2018-2019. The study suggests that although the isolates haven't shown much change about cultural characters, morphology and molecular characterization but they exhibited 
considerable degree of pathogenic variability. The sugarcane genotypes on which differential reaction was produced by the test isolates of F.sacchari could be considered as host differentials on rigorous pathogenicity testing with more isolates of the wilt pathogen. Further, to understand variability within $F$. sacchari, more number of isolates have to be collected from various geographical locations of the country and from different sugarcane genotypes.

\section{Acknowledgement}

The authors are highly thankful to Associate Director of Research, Regional Agricultural Research Station, Anakapalle; Director of Research, ANGRAU for timely support and Funding.

\section{References}

Agnihotri,V.P., and Rao, G.P.: A century status of sugarcane wilt in India. In: Singh SB, Rao GP, Eswaramoorthy S (Eds) Sugarcane Crop Management, Sci Tech Publishing LLC, Houston, USA, pp 145-160 (2002).

Balazy, S., Wrzosek, M., Sosnowska, D., Tkaczuk, C. and Muszewska, A., (2008). Laboratory trials to infect insects and nematodes by some acaropathogenic Hirsutella strains (Mycota: Clavicipitaceous anamorphs). J. Invertebr. Pathol., 97: 103-113.

Bourne BA (1922) Researches on the root diseases of sugarcane. Department of Agriculture, Barbados, pp 1-17

Butler EJ, Khan AH (1913) Some new sugarcane diseases. Part I, Wilt. Memoirs of the Department of Agriculture, India, Botany Series 6, 180-190.

Duggal, A.; Dumas, M.T.; Jeng, R.S. and Hubbes, M. (1997). Ribosomal variation in six species of Fusarium. Mycopath., 140: 35-49.

Fawcett GL (1922) Enfermedades de la cana de azucar en Tucuman. Revista Industrial de Agricultura de Tucuman 13 (1 \& 2), $46 \mathrm{pp}$, illus (Translation of 2nd Edn, Library USDA, Sugarcane and Sweet Sorghum Section)

Gupta MR, Gupta SC (1976) Assessment of losses caused by wilt disease of sugarcane in western UP. Indian Sugar 26, 151-152

Khanna KL, Chacravarti AS (1949) Studies on storage of gur. Current Science 18, 127-128.

Kirtikar, Singh GP, Shukla R (1972) Role of seed material in carry over of wilt disease of sugarcane. Indian Sugar 22, 89-90.

Lenc, L.; Lukanowski and, A. and Sadowski, C.Z. (2008). The use of PCR amplification in determining the toxigenic potential of Fusarium sambucinum and $F$. solani isolated from potato. Phytopathol. Pol., 48: 1323

Nelson PE, Dignani MC, Anaissie EJ (1994a) Taxonomy, biology, and clinical aspects of Fusarium species. Clinical Microbiology Reviews7: 479-504.

O’Donnell, K.; Cigelnikand, E. and Nirenberg, H.I. (1998). Molecular systematics and phylogeography of the Gibberella fujikuroi species. Complex, 90(3): 465493.

Poongothai, M. \& Viswanathan, Rasappa \& Malathi, P. \& Amalraj, Rameshsundar. (2014). Fusarium sacchari causing sugarcane wilt: Variation in morphological characteristics of the pathogen. International Sugar Journal. 116. 54-63.

Poongothai, M., Viswanathan, R., Malathi, P. et al., Sugarcane Wilt: Pathogen Recovery from Different Tissues and Variation in Cultural Characters. Sugar 
Tech 16, 50-66 (2014). https://doi.org/10.1007/s12355-0130249-2.

Sarma MN (1976). Wilt disease of sugarcane. Sugarcane Pathologists Newsletter 15/16, 30-33.

Singh O, Waraitch KS (1981). Effect of wilt and red rot induced stress on quality deterioration of sugarcane. Sugarcane Pathologists Newsletter 27, 25-30.

Viswanathan R, Malathi P, Ramesh Sundar A (2009) Final Report of the Network Project on Wilt of crops with special reference to cultural, morphological, molecular characterization and pathogenic variability of isolates in India, Sugarcane breeding Institute, Coimbatore, $46 \mathrm{pp}$

Viswanathan R, Malathi P, Ramesh Sundar A Poongothai M, Singh N (2006) Current status of sugarcane wilt in India. Sugar Cane International 24 (4), 1-7

Viswanathan R, Rao GP (2011) Disease scenario and management of major sugarcane diseases in India. Sugar
Tech 13, 336-353

Viswanathan, R., Poongothai, M., Malathi, P., and Sundar, AR (2012). Sugarcane Wilt: New Insights into Pathogen Identity, Variability and Pathogenicity. Functional Plant Science and Biotechnology 6 (Special Issue 2), 3039 ๑2012 Global Science Books

Viswanathan, Rasappa. (2013). STATUS OF SUGARCANE WILT: ONE HUNDRED YEARS AFTER ITS OCCURRENCE IN INDIA. Journal of Sugarcane Research. 3. 86-106.

Waraitch KS (1981) Wilt disease in Co 1148 in Punjab and assessment of losses caused by it. Indian Sugar 31, 37-40.

White, T. J., Bruns, T., Lee, S., Taylor J.: Amplification and direct sequencing of fungal ribosomal RNA genes for phylogenetics. In: Innis M. A., Gelfand D. H., Sninsky J. J., White T. J., (eds) PCR Protocols: A guide to methods and applications. Academic, New York. 1990; pp 315-322.

\section{How to cite this article:}

Chandra Sekhar, V., P. Kishore Varma, B. Swapna, M. Suresh and Bharathalakhsmi, M. 2021. Variability of Sugarcane Wilt Pathogen in North Coastal Zone of Andhra Pradesh. Int.J.Curr.Microbiol.App.Sci. 10(02): 3161-3174. doi: https://doi.org/10.20546/ijcmas.2021.1002.347 